\title{
Transmyocardial revascularization devices: technology update
}

\author{
This article was published in the following Dove Press journal: \\ Medical Devices: Evidence and Research \\ 18 December 2014 \\ Number of times this article has been viewed
}

\author{
Bogdan A Kindzelski \\ Yifu Zhou \\ Keith A Horvath \\ Cardiothoracic Surgery Research \\ Program, National Heart, Lung and \\ Blood Institute, National Institutes \\ of Health, Bethesda, MD, USA
}

Correspondence: Keith A Horvath Cardiothoracic Surgery Research Program, National Heart, Lung and Blood Institute, National Institutes of Health, Building I0 Room BID47, 10 Center Drive, Bethesda, MD 20892, USA

$\mathrm{Tel}+\mid$ 30| 45। 7098

$\mathrm{Fax}+\mid$ 30| 45। 5459

Email horvathka@mail.nih.gov
Abstract: Transmyocardial laser revascularization (TMR) emerged as treatment modality for patients with diffuse coronary artery disease not amendable to percutaneous or surgical revascularization. The procedure entails the creation of laser channels within ischemic myocardium in an effort to better perfuse these areas. Currently, two laser devices are approved by the US Food and Drug Administration for TMR - holmium:yttrium-aluminum-garnet and $\mathrm{CO}_{2}$. The two devices differ in regard to energy outputs, wavelengths, ability to synchronize with the heart cycle, and laser-tissue interactions. These differences have led to studies showing different efficacies between the two laser devices. Over 50,000 procedures have been performed worldwide using TMR. Improvements in angina stages, quality of life, and perfusion of the myocardium have been demonstrated with TMR. Although several mechanisms for these improvements have been suggested, evidence points to new blood vessel formation, or angiogenesis, within the treated myocardium, as the major contributory factor. TMR has been used as sole therapy and in combination with coronary artery bypass grafting. Clinical studies have demonstrated that TMR is both safe and effective in angina relief long term. The objective of this review is to present the two approved laser devices and evidence for the safety and efficacy of TMR, along with future directions with this technology.

Keywords: laser, revascularization, angiogenesis, coronary artery disease

\section{Introduction}

As life expectancy and coronary-event survival rates rise, an increasing number of patients with severe coronary artery disease experience angina that is not amenable to percutaneous coronary intervention or surgical revascularization. ${ }^{1-3}$ Moreover, up to $25 \%$ of coronary artery bypass grafting $(\mathrm{CABG})$ patients have incomplete revascularization, a strong independent predictor of operative mortality and morbidity. ${ }^{4,5}$ Therefore, a great deal of interest in alternative strategies to traditional revascularization has been pursued. These experimental approaches include pharmacologic interventions, ${ }^{6}$ enhanced external counterpulsation, ${ }^{7,8}$ spinal cord stimulation, ${ }^{9}$ protein, ${ }^{10}$ gene, ${ }^{11}$ or stem cell therapy ${ }^{12,13}$ to promote angiogenesis (the formation of new blood vessels), and the topic of this discussion - transmyocardial laser revascularization (TMR).

TMR is a US Food and Drug Administration (FDA)-approved intervention utilizing a laser device intended to treat ischemic myocardium. This procedure was approved by the FDA in 1998 to treat moderate to severe angina (class 3-4 based on the Canadian Cardiovascular Society Classification System ${ }^{14}$ - Table 1) as a result of diffuse coronary artery disease not amendable to conventional medical therapy, percutaneous coronary intervention, or surgical revascularization via CABG. Over 50,000 TMR procedures 
Table I Canadian Cardiovascular Society Angina Classification System

\begin{tabular}{ll}
\hline Class & Description \\
\hline I & Ordinary physical activity, such as walking and climbing stairs, \\
& does not cause angina. Angina occurs with strenuous, rapid, \\
& or prolonged exertion at work or recreation. \\
& Slight limitation of ordinary activity. Angina occurs on walking \\
or climbing stairs rapidly; walking uphill; walking or stair \\
climbing after meals, in cold, in wind, or under emotional \\
stress; or only during the few hours after awakening. Angina \\
occurs on walking more than two blocks on the level and \\
climbing more than one flight of ordinary stairs at a normal \\
pace and in normal conditions. \\
Marked limitations of ordinary physical activity. Angina occurs \\
on walking one to two blocks on the level and climbing one \\
flight of stairs in normal conditions and at a normal pace. \\
Inability to carry on any physical activity without discomfort; \\
anginal symptoms may be present at rest.
\end{tabular}

have been performed worldwide in more than 38 countries, with over 20,000 performed in the United States to date. Over the past two decades, results from prospective and retrospective studies on TMR have been reported. ${ }^{15-31} \mathrm{~A}$ few meta-analyses have also been reported, along with an FDA review on short-term and long-term outcomes with the use of TMR. ${ }^{29,31-33}$ This review covers two different FDA-approved devices for TMR, evidence-based practice, and future directions aimed at utilizing a combined TMR and stem cell therapy approach.

\section{Proposed mechanism}

TMR is an approved surgical procedure that induces transmural laser channels within ischemic myocardium. The thought behind direct perfusion to the myocardium was based on descriptions of reptilian heart sinusoids that allowed blood to flow directly from the ventricles into the myocardium, perfusing the heart muscle. TMR creates channels that are $1 \mathrm{~mm}$ in diameter, with the number of channels depending on heart size and ischemic territory (Figure 1). The exact mechanism of angina relief is debated.

Patent channels that allow perfusion from the ventricle to the myocardium may provide a potential mechanism for TMR and angina relief. Clinical and experimental work have shown evidence of long-term patency. ${ }^{34,35}$ However, several autopsy case reports and reviews have demonstrated that channels created by TMR in humans do not remain patent. ${ }^{35-39}$ Therefore, it is believed that patency of channels providing perfusion to the ischemic myocardium is not the mechanism of action for TMR.

Denervation of the sympathetic nerve fibers innervating the heart is another proposed mechanism of angina relief following TMR. Afferent, sympathetic efferent postganglionic,

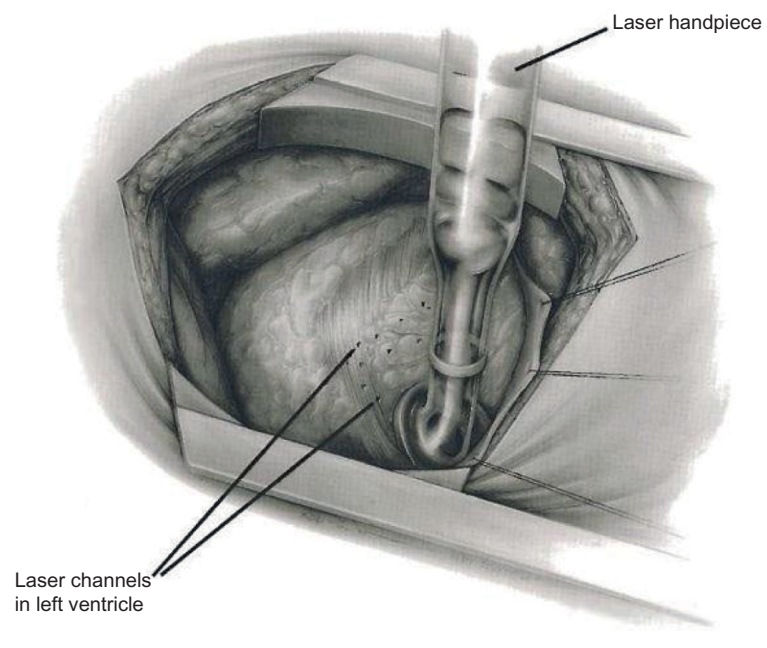

Figure I Illustration showing left thoracotomy and exposure of the heart for TMR. Notes: The handpiece and I $\mathrm{mm}$ transmural channels in the myocardium are shown. The channels are created one per square centimeter, beginning inferiorly and moving superiorly to the anterior section of the heart. Total channel number depends on size and ischemic territory.

Abbreviation: TMR, transmyocardial revascularization.

and parasympathetic efferent postganglionic neurons all innervate the heart. Conflicting experimental evidence has been reported regarding denervation playing a role in angina relief. ${ }^{40-42}$ These experiments only focused on short-term results. Furthermore, it is difficult to assess and isolate the afferent nerves involved in pain signaling. A study by Al-Sheikh et $\mathrm{al}^{43}$ utilizing positron emission tomography scanning demonstrated that sympathetic denervation occurs following TMR. Nevertheless, evidence indicating that denervation is the primary cause of angina relief is lacking.

Angiogenesis has shown the strongest experimental and clinical evidence for being the primary basis of angina relief after TMR. Several independent groups have provided concrete histological evidence of increased angiogenesis and neovascularization as a direct result of TMR channel creation. ${ }^{44-48}$ Additionally, upregulation of proangiogenic factors, such as vascular endothelial growth factor, fibroblast growth factor 2, and platelet-derived endothelial cell growth factor, was demonstrated in myocardial tissue following TMR. $^{49-51}$ This neovascularization process is not specific to laser only, but can also be seen with other means of myocardial channel formation, such as hot and cold needles and radiofrequency ablation. However, TMR minimizes scar formation, which allows optimal functional contribution of the new blood vessels. Therefore, the evidence from a histological and molecular standpoint supports the notion of angiogenesis promotion in the ischemic heart following TMR, with the minimization of scar tissue following channel creation. 
Another critical issue explored by several studies is the notion that angiogenesis following TMR may lead to improvement in heart function. Improvement in subjective quality of life was shown following TMR. ${ }^{25}$ Moreover, objective improvements were demonstrated based on dobutamine stress echocardiography, positron emission tomography scanning, and cardiac magnetic resonance imaging (MRI). ${ }^{52-55}$ Improvements in perfusion and myocardial function were noted in animal models of chronic myocardial ischemia as well, supporting the proangiogenic basis of improvement. ${ }^{56-59}$ The role of angiogenesis was further supported by a study that showed emergence of small vessels perfusing the heart on follow-up angiography 10 years after TMR. ${ }^{60}$ These secondary blood vessels were not present prior to TMR. Thus, neovascularization and angiogenesis seem to be the predominant driving force for angina improvement and increased myocardial perfusion.

\section{Devices}

Many different wavelengths of laser light have been studied experimentally, including xenon-chloride, ${ }^{61}$ neodymium:yttrium-aluminum-garnet (YAG), ${ }^{62}$ erbium:YAG ${ }^{63}$ thulium-holmium-chromium:YAG ${ }^{64}$ holmium:YAG (Ho:YAG), ${ }^{61}$ and $\mathrm{CO}_{2}{ }^{65}$ Two different laser devices are currently FDA-approved and utilized for TMR (Figure 2) - the Heart Laser $\mathrm{CO}_{2}$ Transmyocardial Revascularization System (Novadaq Technologies Inc., BC, Canada) and the SolarGen TMR Ho:YAG Laser System
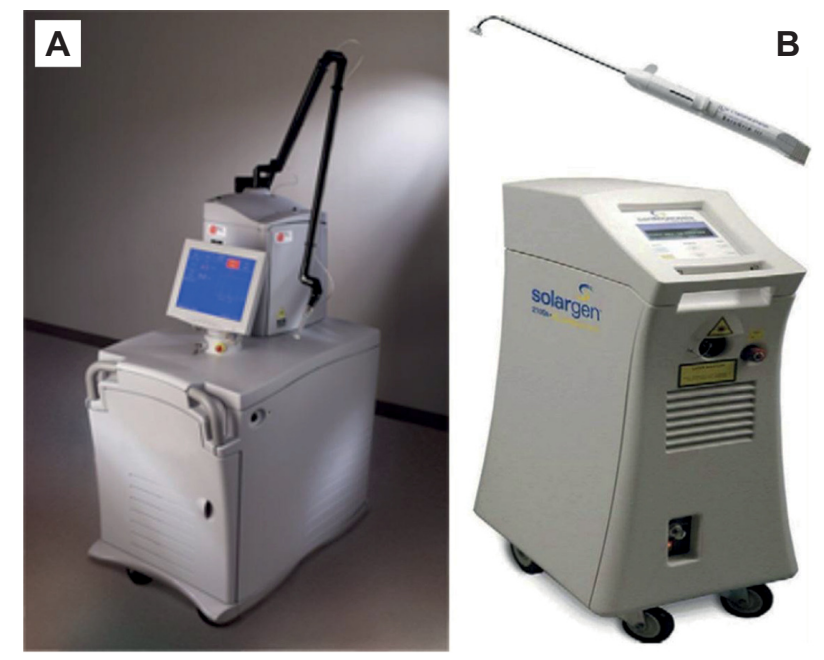

Figure 2 Transmyocardial revascularization lasers.

Notes: (A) Heart Laser $\mathrm{CO}_{2}$ Transmyocardial Revascularization System (Novadaq Technologies Inc., BC, Canada). (B) SolarGen TMR Ho:YAG Laser System (CardioGenesis Corporation, Foothill Ranch, CA, USA) with associated fiberoptic handpiece.

Abbreviations: Ho:YAG, holmium:yttrium-aluminum-garnet; TMR, transmyocardial revascularization.
(CardioGenesis Corporation, Foothill Ranch, CA, USA). In addition to different wavelengths, these lasers employ different energy outputs and require slightly different surgical approaches.

The $\mathrm{CO}_{2}$ laser has a wavelength of $10,600 \mathrm{~nm}$ and uses an energy level of 15-20 J per pulse with a pulse duration of $25-40 \mathrm{~ms}$. A single pulse is used, and the pulse beam is directed within the device to the myocardium using a system of mirrors (Figure 3). Using this level of energy and single pulses, the laser photons do not create tissue explosions, limiting the total structural damage (Figure 4). The $\mathrm{CO}_{2}$ laser is also synchronized with the R-wave (maximal ventricular filling) of the electrocardiogram cycle. Transesophageal echocardiography can be used to confirm accurate transmural channel formation, as a result of vaporization of blood within the ventricle. This characteristic acoustic response is helpful in assessing whether proper laser pulse delivery was achieved.

In contrast to the $\mathrm{CO}_{2}$ laser, the Ho:YAG laser system has a wavelength of 2,120 nm and uses pulsed laser beam sequences of 1-2 J and 6-8 $\mathrm{W}$ per pulse. This laser beam is projected through a $1 \mathrm{~mm}$ fiberoptic bundle at a rate of five pulses per second. The arrival of the sequential pulses must be separated by time in order to allow for proper thermal dissipation to avoid excess heat accumulation. If the pulses are incorrectly timed, this can lead to tissue explosions and subsequent structural trauma, along with thermocoagulation. ${ }^{66}$ Even with the pulsed low sequences, high levels of peak

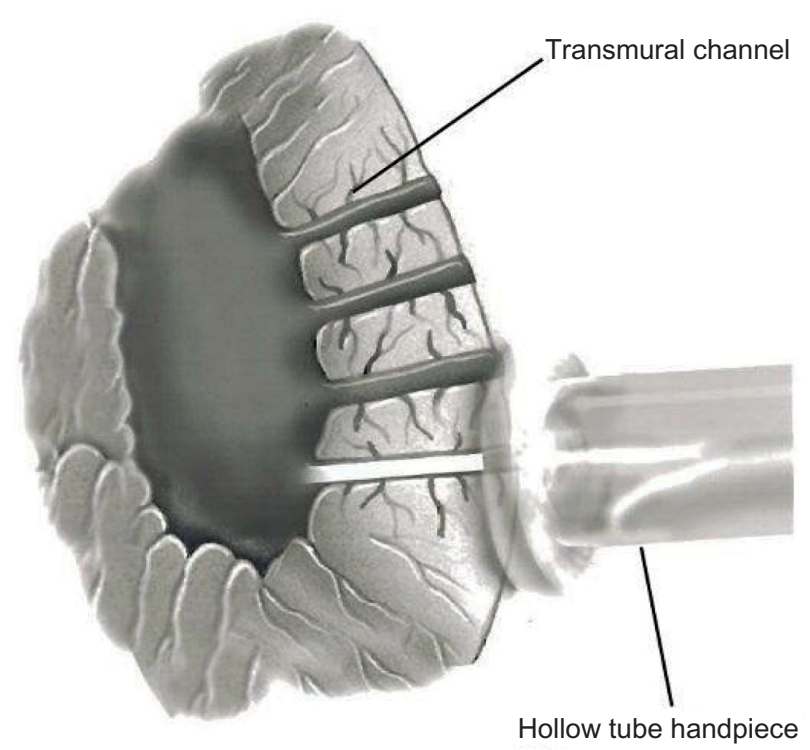

Figure 3 Illustration of $\mathrm{CO}_{2}$ laser.

Notes: Energy from the laser is delivered via hollow tubes and is reflected by mirrors to reach the epicardial surface of the heart. Transmural channels are created using a single $20 \mathrm{~J}$ pulse. 
A

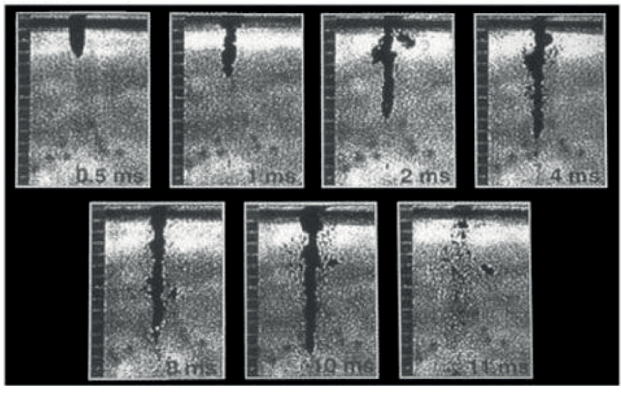

B

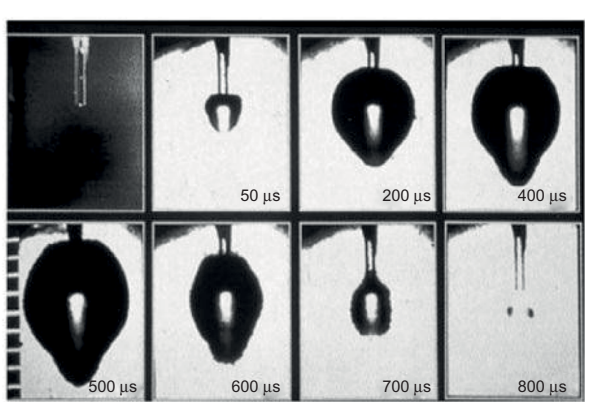

Figure 4 Stop-action photography of laser pulses.

Notes: (A) Stop-action photography of laser pulses created with the $\mathrm{CO}_{2}$ laser. The $\mathrm{CO}_{2}$ laser creates a clean and straight channel within the tissue. (B) Stop-action photography of laser pulses created with the Ho:YAG laser. The Ho:YAG laser creates wider explosive ablations within the tissue.

Abbreviation: Ho:YAG, holmium:yttrium-aluminum-garnet.

power are delivered to the tissue, causing small explosions (Figure 4). During the procedure using the Ho:YAG laser, the laser fiber is advanced manually through the myocardium. Due to this physical manipulation, it is not possible to decipher whether the channel in the myocardium is being created as a result of the mechanical effects of the fiber or whether there has been enough time for thermal dissipation to occur prior to the next initiated pulse. Furthermore, the Ho:YAG laser is unsynchronized to the cardiac cycle and is prone to producing ventricular arrhythmias.

\section{TMR sole therapy}

TMR has been performed solely or in combination with other procedures, such as CABG. Sole TMR may be done without the use of cardiopulmonary bypass or anticoagulation. The procedure requires general anesthesia, generally done via a double-lumen endotracheal tube or bronchial blocker to isolate the left lung. Exposure to the left ventricle is obtained via a left anterolateral thoracotomy performed on the fifth intercostal space. Upon laser activation, transesophageal echocardiography is used to monitor whether a successful channel was created with the $\mathrm{CO}_{2}$ laser. Channel formation using the Ho:YAG laser is monitored by tactile and auditory feedback. Upon completion, a chest tube is placed and the thoracotomy is closed. In most cases, the patient is extubated in the operating room.

Preliminary nonrandomized trials showed benefit for sole TMR in patients with diffuse coronary artery disease and no other options to alleviate severe angina. ${ }^{15-17}$ This symptomatic improvement led to prospective randomized control trials, which were designed to test TMR plus optimal medical management versus optimal medical management alone. ${ }^{22-26}$ Over 1,200 patients were enrolled in these trials. In order to fit inclusion and exclusion criteria, all patients had refractory angina that was not amenable to percutaneous coronary intervention or CABG (confirmed on recent angiogram), evidence of reversible ischemia upon myocardial perfusion scanning, and a left ventricular ejection fraction greater than $25 \%$. Three of the five trials used the $\mathrm{CO}_{2}$ laser, ${ }^{24-26}$ and two trials used the Ho:YAG laser. ${ }^{22,23}$ The major subjective endpoint investigated entailed a change in angina symptoms. Other study endpoints included: operative mortality, 1-year survival, myocardial perfusion, exercise tolerance, quality of life, cardiac-related hospitalizations, and major adverse events. Patients were evaluated and assessed at 3 months, 6 months, and 12 months following randomization.

Significant angina improvement was seen in all studies (Figure 5). Based on all five clinical trials, a summary odds ratio of $9.3(95 \%$ confidence interval $=4.6-18.5 ; P<0.001)$ for angina reduction was calculated. Moreover, quality of life, freedom from rehospitalization at 1 year, exercise tolerance, and decreased need for nitrates were significantly improved

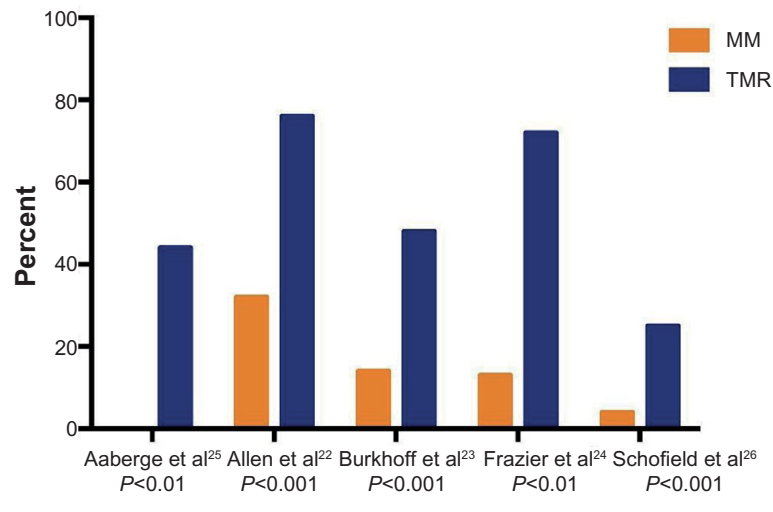

Figure 5 Angina relief at 12 months.

Notes: Summary of angina relief in five randomized controlled trials at I-year followup as defined by a decrease of two or more angina classes. Column graph illustrates differences between medical management and transmyocardial revascularization plus medical management groups. Corresponding $P$-values are shown below the bars. Abbreviations: MM, medical management; TMR, transmyocardial revascularization. 
in patients who received laser treatment. A meta-analysis looking at 1-year survival in randomized patients showed similar survival between patients treated with laser and those managed with medical therapy alone. ${ }^{32}$ Functional analysis looking at myocardial perfusion showed some evidence of improvement in reversible ischemic defects and perfusion of ischemic territories with the $\mathrm{CO}_{2}$ laser. ${ }^{24,26}$

Long-term follow-up of the prospective randomized controlled trials showed continued angina relief in the TMR group. Specifically, intention-to-treat analyses showed that at a mean of 5 years, $88 \%$ of patients who received TMR experienced at least a 2 -level reduction in angina class, compared with $44 \%$ of patients managed medically $(P<0.001) .{ }^{67}$ Furthermore, long-term analysis of a trial that did not allow crossover between groups showed an improvement in angina symptoms $(P<0.001)$ and reduction in unstable angina hospitalizations in the TMR group $(P<0.05)$ at 43 months of follow-up. ${ }^{25}$ A long-term outcome analysis conducted by the FDA, Society of Thoracic Surgeons, and Duke Clinical Research Institute showed that there were no differences in long-term morbidity or mortality between $\mathrm{CO}_{2}$ and Ho:YAG lasers used for sole TMR. ${ }^{29}$ On the basis of the evidence demonstrated by the randomized clinical trials, both the American College of Cardiology/American Heart Association and the Society of Thoracic Surgeons have provided practice guidelines favoring the use of TMR in patients with medically refractive angina not amenable to revascularization procedures. ${ }^{68,69}$

\section{CABG plus adjuvant TMR}

TMR plus CABG is reserved for patients who have ischemia that is able to be bypassed coupled with ischemic zones not amenable to bypass grafting. This combined procedure may be performed with or without the use of cardiopulmonary bypass. Both $\mathrm{CO}_{2}$ and Ho:YAG lasers have been used with this hybrid approach. The efficacy of CABG plus TMR has been challenging to assess, due to the inability to delineate the influence of coronary bypass grafts and also the lack of randomized controlled arms in several studies. ${ }^{70-72}$

Only two randomized controlled trials assessing CABG plus adjuvant TMR versus CABG alone have been reported. ${ }^{73,74}$ In these trials, patients were blinded to treatment assignment through 1 year of follow-up. Patient characteristics and number of bypass grafts were similar between groups. Outcomes from one of the trials showed reduced postoperative mortality ( $1.5 \%$ versus $7.6 \%, P=0.02)$, increased 30 -day freedom from major adverse cardiac events $(97 \%$ versus $91 \%, P=0.04$ ), and improved 1-year Kaplan-Meier survival
(95\% versus $89 \%, P=0.05) .{ }^{73}$ The other trial showed a similar trend in postoperative mortality within high-risk patients $(9 \%$ versus $33 \%, P=0.09) .{ }^{74}$ On subsequent 4 -year follow-up of these patients, survival was similar between groups; however, there was an increase in the need for revascularization in the CABG-alone group $(24 \%$ versus $0 \%, P<0.05) .^{75}$ Furthermore, a retrospective study showed no difference in survival between TMR plus CABG and CABG-alone groups, although with 4-year follow-up in the TMR plus CABG group there was a sustained improvement in New York Heart Association Classification $(P<0.001) .{ }^{76}$ No differences in long-term outcomes for morbidity and mortality were noted between $\mathrm{CO}_{2}$ and $\mathrm{Ho}$ :YAG lasers used in combination with CABG. $^{29}$

\section{Percutaneous TMR}

In an attempt to reduce perioperative morbidity, a minimally invasive percutaneous approach to myocardial revascularization has been previously pursed. ${ }^{77,78}$ This approach is carried out using a laser fiber inserted into a peripheral artery and guided into the left ventricle. Electromechanical mapping is used to verify the fiber position within the heart. The fiber utilized Ho:YAG laser to create 2-3-mm-deep divots in the subendocardial tissue.

Results with percutaneous myocardial revascularization (PMR) have been less favorable than those observed with TMR. ${ }^{79-81}$ Furthermore, a pilot study evaluating the efficacy of PMR in combination with percutaneous coronary intervention showed a high rate of periprocedural adverse events $(11.5 \%){ }^{82}$ Given these results, the FDA has rendered PMR unapprovable. The failure associated with PMR may result from several factors. The maximal depth of channel formation is only $6 \mathrm{~mm}$ with PMR. This is significantly less than the full-thickness channel formation found with TMR. Additionally, fewer channels are created with PMR. The exact location of channel formation is also a critical issue within the beating ventricle. Lastly, there are inherent limitations with using the Ho:YAG laser in PMR.

\section{TMR plus adjuvant cell therapy}

A plethora of research has centered on cell therapy in an effort to stimulate angiogenesis and myogenesis for heart disease. Stem cells, including hematopoietic stem cells, endothelial progenitor cells, mesenchymal stem cells, myoblasts, and undifferentiated side-population cells, have been used clinically with various routes of administration for ischemic heart disease. ${ }^{83-90}$ Of the different cells studied, bone marrow stem cells have shown promise. It is believed that bone marrow stem cells 


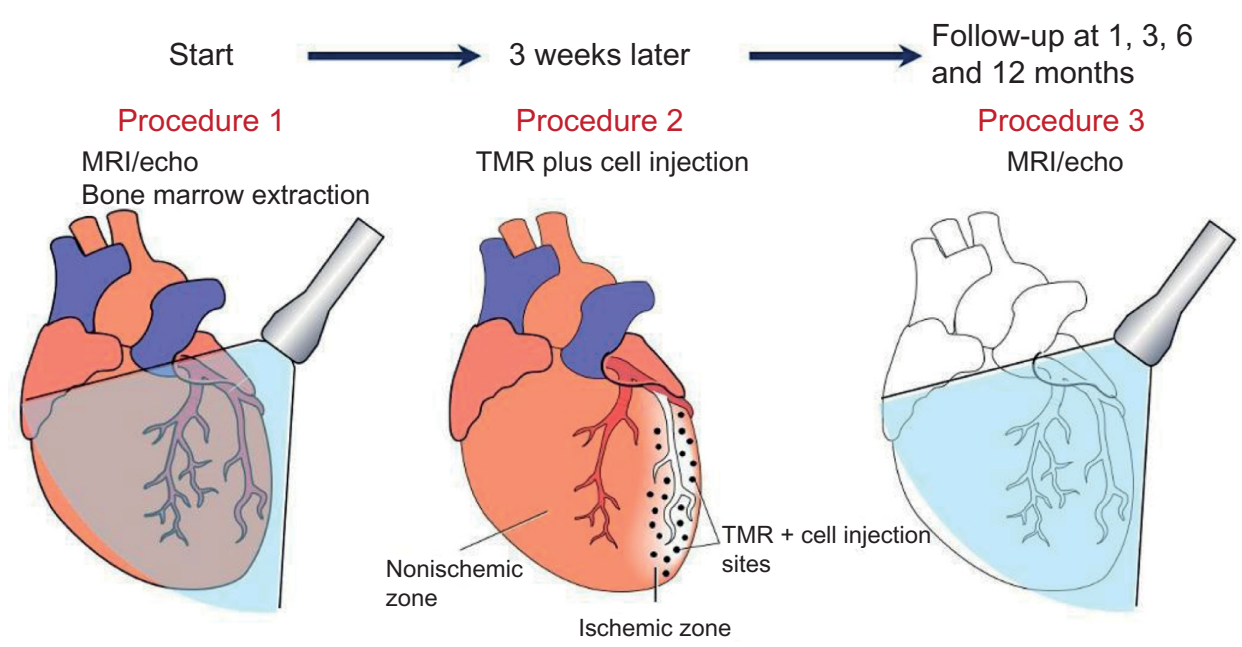

Figure 6 Procedural timeline for NIH Clinical Trial (NCT0I557543) in patients undergoing TMR plus direct mesenchymal stem cell injections.

Notes: Preoperative MRI and echocardiography are done along with bone marrow harvest 3 weeks before TMR procedure. Mesenchymal stem cells are isolated from bone marrow and expanded ex vivo. Following laser channel creation during TMR, mesenchymal stem cells are injected into the ischemic myocardium. Follow-up MRI and echocardiography are done at I month, 3 months, 6 months, and 12 months and compared to baseline imaging.

Abbreviations: MRI, magnetic resonance imaging; NIH, National Institutes of Health; TMR, transmyocardial revascularization.

promote the paracrine secretion of growth factors and cytokines, which stimulate angiogenesis and aid in the survival of cardiomyocytes through the mobilization of progenitor cells.

The combination of cell therapy and TMR has been studied in both animal models ${ }^{91}$ and in several clinical studies. ${ }^{92-97}$ One group showed that TMR assisted in mesenchymal stem cell engraftment in rat hearts, with corresponding increases in expression of stem cell factor, stromal derived factor-1, c-kit, and chemokine receptor type 4 , as compared to control rats who received only stem cells. ${ }^{98}$ Clinical studies of mesenchymal stem cells plus TMR include individual case reports or series of patients with angina refractory to $\mathrm{CABG}$ or percutaneous coronary intervention. The bone marrow stem cells that were transplanted were autologous and harvested on the same day of surgery. All of these studies demonstrated that injection of stem cells in addition to TMR was safe and showed an improvement in angina class. Several studies showed some evidence of improvement in perfusion and left ventricular contractility. ${ }^{94-96}$ One of the major limitations of these studies is lack of differentiation between the effects of injected autologous stem cells versus laser revascularization. Furthermore, these studies may have been limited as a result of the small number of cells being injected due to no ex vivo expansion of these stem cells prior to injection. Future investigation into the concomitant use of cell therapy and TMR is warranted.

Our group is currently working on an NIH-sponsored clinical trial (NCT01557543) to study the effects of direct injection of ex-vivo-expanded autologous mesenchymal stem cells in patients undergoing CABG or TMR using the $\mathrm{CO}_{2}$ laser
(Figure 6). The outcomes of interest include cardiac function, quality of life, and reduction of cardiac events in patients versus historical controls at 3 months and 6 months after intervention. With expansion of the autologous mesenchymal stem cells ex vivo coupled with direct injection into the myocardium, we believe this technique should provide further clinical benefit in addition to the CABG or TMR procedure.

\section{Conclusion}

TMR is a surgical procedure pioneered in the 1990s that provides angina relief to patients with diffuse coronary disease. The predominant theory behind improvement involves myocardial angiogenesis leading to increased perfusion. Both Ho: $Y A G$ and $\mathrm{CO}_{2}$ laser devices have been approved by the FDA. TMR can be combined with CABG to target ischemic areas that cannot be readily bypassed. Safety of the procedure and long-term angina relief has been shown both with sole TMR and with CABG plus adjuvant TMR. PMR with the use of Ho:YAG has been attempted as a minimally invasive option of TMR, yet it has demonstrated less-favorable results than TMR. Finally, current efforts have been aimed at combining TMR with adjuvant stem cell therapy to better improve functional outcomes in patients.

\section{Disclosure}

The authors have no commercial associations or financial disclosures that might pose or create a conflict of interest with information presented in this manuscript (such associations include consultancies, stock ownership, or other equity interests, patent licensing arrangements, and payments 
for conducting or publicizing a study described in the manuscript). The authors report no other conflicts of interest in this work.

\section{References}

1. Mannheimer C, Camici P, Chester MR, et al. The problem of chronic refractory angina; report from the ESC Joint Study Group on the Treatment of Refractory Angina. Eur Heart J. 2002;23(5): 355-370.

2. Jolicoeur EM, Granger CB, Henry TD, et al; Working Group Members. Clinical and research issues regarding chronic advanced coronary artery disease: part I: Contemporary and emerging therapies. Am Heart J. 2008;155(3):418-434.

3. Jolicoeur EM, Ohman EM, Temple R, et al; Working Group Members. Clinical and research issues regarding chronic advanced coronary artery disease part II: Trial design, outcomes, and regulatory issues. Am Heart J. 2008;155(3):435-444.

4. Weintraub WS, Jones EL, Craver JM, Guyton RA. Frequency of repeat coronary bypass or coronary angioplasty after coronary artery bypass surgery using saphenous venous grafts. Am J Cardiol. 1994;73(2): 103-112.

5. Osswald BR, Blackstone EH, Tochtermann U, et al. Does the completeness of revascularization affect early survival after coronary artery bypass grafting in elderly patients? Eur J Cardiothorac Surg. 2001;20(1):120-125.

6. Patel PD, Arora RR. Utility of ranolazine in chronic stable angina patients. Vasc Health Risk Manag. 2008;4(4):819-824.

7. Arora RR, Chou TM, Jain D, et al. The multicenter study of enhanced external counterpulsation (MUST-EECP): effect of EECP on exerciseinduced myocardial ischemia and anginal episodes. J Am Coll Cardiol. 1999;33(7):1833-1840.

8. Manchanda A, Soran O. Enhanced external counterpulsation and future directions: step beyond medical management for patients with angina and heart failure. J Am Coll Cardiol. 2007;50(16):1523-1531.

9. Eckert S, Horstkotte D. Management of angina pectoris: the role of spinal cord stimulation. Am J Cardiovasc Drugs. 2009;9(1):17-28.

10. Simons M, Annex BH, Laham RJ, et al. Pharmacological treatment of coronary artery disease with recombinant fibroblast growth factor-2: double-blind, randomized, controlled clinical trial. Circulation. 2002;105(7):788-793.

11. Kastrup J, Jørgensen E, Rück A, et al; Euroinject One Group. Direct intramyocardial plasmid vascular endothelial growth factor-A165 gene therapy in patients with stable severe angina pectoris A randomized double-blind placebo-controlled study: the Euroinject One trial. $J \mathrm{Am}$ Coll Cardiol. 2005;45(7):982-988.

12. Zhou Y, Wang S, Yu Z, Hoyt RF Jr, Qu X, Horvath KA. Marrow stromal cells differentiate into vasculature after allogeneic transplantation into ischemic myocardium. Ann Thorac Surg. 2011;91(4):1206-1212.

13. Boomsma RA, Geenen DL. Mesenchymal stem cells secrete multiple cytokines that promote angiogenesis and have contrasting effects on chemotaxis and apoptosis. PLoS One. 2012;7(4):e35685.

14. Campeau L. Letter: Grading of angina pectoris. Circulation. 1976;54(3): 522-523.

15. Horvath KA, Mannting F, Cummings N, Shernan SK, Cohn LH. Transmyocardial laser revascularization: operative techniques and clinical results at two years. J Thorac Cardiovasc Surg. 1996;111(5): 1047-1053.

16. Cooley DA, Frazier OH, Kadipasaoglu KA, et al. Transmyocardial laser revascularization: clinical experience with twelve-month follow-up. J Thorac Cardiovasc Surg. 1996;111(4):791-797; discussion 797-799.

17. Horvath KA, Cohn LH, Cooley DA, et al. Transmyocardial laser revascularization: results of a multicenter trial with transmyocardial laser revascularization used as sole therapy for end-stage coronary artery disease. J Thorac Cardiovasc Surg. 1997;113(4):645-653; discussion 653-654.
18. Krabatsch T, Tambeur L, Lieback E, Shaper F, Hetzer R. Transmyocardial laser revascularization in the treatment of end-stage coronary artery disease. Ann Thorac Cardiovasc Surg. 1998;4(2):64-71.

19. Hattler BG, Griffith BP, Zenati MA, et al. Transmyocardial laser revascularization in the patient with unmanageable unstable angina. Ann Thorac Surg. 1999;68(4):1203-1209.

20. Milano A, Pratali S, Tartarini G, et al. Early results of transmyocardial revascularization with a holmium laser. Ann Thorac Surg. 1998;65(3): 700-704.

21. Dowling RD, Petracek MR, Selinger SL, Allen KB. Transmyocardial revascularization in patients with refractory, unstable angina. Circulation. 1998;98(Suppl 19):II73-II75; discussion II75-II76.

22. Allen KB, Dowling RD, Fudge TL, et al. Comparison of transmyocardial revascularization with medical therapy in patients with refractory angina. N Engl J Med. 1999;341(14):1029-1036.

23. Burkhoff D, Schmidt S, Schulman SP, et al. Transmyocardial laser revascularisation compared with continued medical therapy for treatment of refractory angina pectoris: a prospective randomised trial. ATLANTIC Investigators. Angina Treatments-Lasers and Normal Therapies in Comparison. Lancet. 1999;354(9182):885-890.

24. Frazier OH, March RJ, Horvath KA. Transmyocardial revascularization with a carbon dioxide laser in patients with end-stage coronary artery disease. N Engl J Med. 1999;341(14):1021-1028.

25. Aaberge L, Rootwelt K, Blomhoff S, Saatvedt K, Abdelnoor M, Forfang K. Continued symptomatic improvement three to five years after transmyocardial revascularization with $\mathrm{CO}(2)$ laser: a late clinical follow-up of the Norwegian Randomized trial with transmyocardial revascularization. J Am Coll Cardiol. 2002;39(10):1588-1593.

26. Schofield PM, Sharples LD, Caine N, et al. Transmyocardial laser revascularisation in patients with refractory angina: a randomised controlled trial. Lancet. 1999;353(9152):519-524.

27. Jones JW, Schmidt SE, Richman BW, et al. Holmium:YAG laser transmyocardial revascularization relieves angina and improves functional status. Ann Thorac Surg. 1999;67(6):1596-1601; discussion 1601-1602.

28. Horvath KA. Results of prospective randomized controlled trials of transmyocardial laser revascularization. Heart Surg Forum. 2002;5(1): 33-39.

29. Tavris DR, Brennan JM, Sedrakyan A, et al. Long-term outcomes after transmyocardial revascularization. Ann Thorac Surg. 2012;94(5): $1500-1508$

30. Horvath KA, Aranki SF, Cohn LH, et al. Sustained angina relief 5 years after transmyocardial laser revascularization with a $\mathrm{CO}(2)$ laser. Circulation. 2001;104(12 Suppl 1):I81-I84.

31. Briones E, Lacalle JR, Marin I. Transmyocardial laser revascularization versus medical therapy for refractory angina. Cochrane Database Syst Rev. 2009;(1):CD003712.

32. Cheng D, Diegeler A, Allen K, et al. Transmyocardial laser revascularization: a meta-analysis and systematic review of controlled trials. Innovations (Phila). 2006;1(6):295-313.

33. Liao L, Sarria-Santamera A, Matchar DB, et al. Meta-analysis of survival and relief of angina pectoris after transmyocardial revascularization. Am J Cardiol. 2005;95(10):1243-1245.

34. Cooley DA, Frazier OH, Kadipasaoglu KA, Pehlivanoglu S, Shannon RL, Angelini P. Transmyocardial laser revascularization. Anatomic evidence of long-term channel patency. Tex Heart Inst J. 1994;21(3): 220-224.

35. Horvath KA, Smith WJ, Laurence RG, Schoen FJ, Appleyard RF, Cohn LH. Recovery and viability of an acute myocardial infarct after transmyocardial laser revascularization. J Am Coll Cardiol. 1995;25(1): $258-263$.

36. Krabatsch T, Schäper F, Leder C, Tülsner J, Thalmann U, Hetzer R. Histological findings after transmyocardial laser revascularization. J Card Surg. 1996;11(5):326-331.

37. Gassler N, Wintzer HO, Stubbe HM, Wullbrand A, Helmchen U. Transmyocardial laser revascularization. Histological features in human nonresponder myocardium. Circulation. 1997;95(2):371-375. 
38. BurkhoffD, Fisher PE, Apfelbaum M, Kohmoto T, DeRosa CM, Smith CR. Histologic appearance of transmyocardial laser channels after 4 1/2 weeks. Ann Thorac Surg. 1996;61(5):1532-1534; discussion $1534-1535$.

39. Sigel JE, Abramovitch CM, Lytle BW, Ratliff NB. Transmyocardial laser revascularization: three sequential autopsy cases. $J$ Thorac Cardiovasc Surg. 1998;115(6):1381-1385.

40. Kwong KF, Kanellopoulos GK, Nikols JC, et al. Transmyocardial laser treatment denervates canine myocardium. J Thorac Cardiovasc Surg. 1997;114(6):883-889; discussion 889-890.

41. Hirsch GM, Thompson GW, Arora RC, Hirsch KJ, Sullivan JA, Armour JA. Transmyocardial laser revascularization does not denervate the canine heart. Ann Thorac Surg. 1999;68(2):460-468; discussion 468-469.

42. Minisi AJ, Topaz O, Quinn MS, Mohanty LB. Cardiac nociceptive reflexes after transmyocardial laser revascularization: implications for the neural hypothesis of angina relief. J Thorac Cardiovasc Surg. 2001;122(4):712-719.

43. Al-Sheikh T, Allen KB, Straka SP, et al. Cardiac sympathetic denervation after transmyocardial laser revascularization. Circulation. 1999;100(2):135-140.

44. Fisher PE, Khomoto T, DeRosa CM, Spotnitz HM, Smith CR, BurkhoffD. Histologic analysis of transmyocardial channels: comparison of $\mathrm{CO} 2$ and holmium:YAG lasers. Ann Thorac Surg. 1997;64(2):466-472.

45. Zlotnick AY, Ahmad RM, Reul RM, Laurence RG, Aretz HT, Cohn LH. Neovascularization occurs at the site of closed laser channels after transmyocardial laser revascularization. Surg Forum. 1996;48:286-287.

46. Kohmoto T, Fisher PE, DeRosa C, Smith CR, Burkhoff D. Evidence of angiogenesis in regions treated with transmyocardial laser revascularization. Circulation. 1996;94(8):1714.

47. Spanier T, Smith CR, Burkhoff D. Angiogenesis: a possible mechanism underlying the clinical benefits of transmyocardial laser revascularization. J Clin Laser Med Surg. 1997;15(6):269-273.

48. Hughes GC, Lowe JE, Kypson AP, et al. Neovascularization after transmyocardial laser revascularization in a model of chronic ischemia. Ann Thorac Surg. 1998;66(6):2029-2036.

49. Horvath KA, Chiu E, Maun DC, et al. Up-regulation of vascular endothelial growth factor mRNA and angiogenesis after transmyocardial laser revascularization. Ann Thorac Surg. 1999;68(3):825-829.

50. Li W, Chiba Y, Kimura T, et al. Transmyocardial laser revascularization induced angiogenesis correlated with the expression of matrix metalloproteinases and platelet-derived endothelial cell growth factor. Eur J Cardiothorac Surg. 2001;19(2):156-163.

51. Pelletier MP, Giaid A, Sivaraman S, et al. Angiogenesis and growth factor expression in a model of transmyocardial revascularization. Ann Thorac Surg. 1998;66(1):12-18.

52. Donovan CL, Landolfo KP, Lowe JE, Clements F, Coleman RB, Ryan T. Improvement in inducible ischemia during dobutamine stress echocardiography after transmyocardial laser revascularization in patients with refractory angina pectoris. J Am Coll Cardiol. 1997;30(3):607-612.

53. Frazier OH, Cooley DA, Kadipasaoglu KA, et al. Myocardial revascularization with laser. Preliminary findings. Circulation. 1995; 92(Suppl 9):II58-II65.

54. Laham RJ, Simons M, Pearlman JD, Ho KK, Baim DS. Magnetic resonance imaging demonstrates improved regional systolic wall motion and thickening and myocardial perfusion of myocardial territories treated by laser myocardial revascularization. J Am Coll Cardiol. 2002;39(1):1-8.

55. Horvath KA, Kim RJ, Judd RM, Parker MA, Fullerton DA. Contrast enhanced MRI assessment of microinfarction after transmyocardial laser revascularization. Circulation. 2000;102(18):II-765.

56. Horvath KA, Greene R, Belkind N, Kane B, McPherson DD, Fullerton DA. Left ventricular functional improvement after transmyocardial laser revascularization. Ann Thorac Surg. 1998;66(3):721-725.

57. Hughes GC, Kypson AP, St Louis JD, et al. Improved perfusion and contractile reserve after transmyocardial laser revascularization in a model of hibernating myocardium. Ann Thorac Surg. 1999;67(6): 1714-1720.
58. Krabatsch T, Modersohn D, Konertz W, Hetzer R. Acute changes in functional and metabolic parameters following transmyocardial laser revascularization: an experimental study. Ann Thorac Cardiovasc Surg. 2000;6(6):383-388.

59. Lutter G, Martin J, von Samson P, Heilmann C, Sarai K, Beyersdorf F. Microperfusion enhancement after TMLR in chronically ischemic porcine hearts. Cardiovasc Surg. 2001;9(3):281-291.

60. Sansone F, Dato GM, Zingarelli E, et al. Late angiograms ten years after transmyocardial laser revascularization. Coron Artery Dis. 2011;22(8): $583-584$.

61. Hughes GC, Kypson AP, Annex BH, et al. Induction of angiogenesis after TMR: a comparison of holmium: YAG, $\mathrm{CO} 2$, and excimer lasers. Ann Thorac Surg. 2000;70(2):504-509.

62. Whittaker P, Spariosu K, Ho ZZ. Success of transmyocardial laser revascularization is determined by the amount and organization of scar tissue produced in response to initial injury: results of ultraviolet laser treatment. Lasers Surg Med. 1999;24(4):253-260.

63. Genyk IA, Frenz M, Ott B, Walpoth BH, Schaffner T, Carrel TP. Acute and chronic effects of transmyocardial laser revascularization in the nonischemic pig myocardium by using three laser systems. Lasers Surg Med. 2000;27(5):438-450.

64. Yano OJ, Bielefeld MR, Jeevanandam V, et al. Prevention of acute regional ischemia with endocardial laser channels. Ann Thorac Surg. 1993;56(1):46-53.

65. Horvath KA. Clinical studies of TMR with the CO2 laser. J Clin Laser Med Surg. 1997;15(6):281-285.

66. Kadipaşaoglu KA, Sartori M, Masai T, et al. Intraoperative arrhythmias and tissue damage during transmyocardial laser revascularization. Ann Thorac Surg. 1999;67(2):423-431.

67. Allen KB, Dowling RD, Angell WW, et al. Transmyocardial revascularization: 5-year follow-up of a prospective, randomized multicenter trial. Ann Thorac Surg. 2004;77(4):1228-1234.

68. Gibbons RJ, Abrams J, Chatterjee K, et al; American College of Cardiology; American Heart Association Task Force on Practice Guidelines. Committee on the Management of Patients With Chronic Stable Angina. ACC/AHA 2002 guideline update for the management of patients with chronic stable angina - summary article: a report of the American College of Cardiology/American Heart Association Task Force on Practice Guidelines (Committee on the Management of Patients With Chronic Stable Angina). Circulation. 2003;107(1):149-158.

69. Bridges CR, Horvath KA, Nugent WC, et al; Society of Thoracic Surgeons. The Society of Thoracic Surgeons practice guideline series: transmyocardial laser revascularization. Ann Thorac Surg. 2004;77(4): $1484-1502$.

70. Trehan N, Mishra M, Bapna R, Mishra A, Maheshwari P, Karlekar A. Transmyocardial laser revascularisation combined with coronary artery bypass grafting without cardiopulmonary bypass. Eur J Cardiothorac Surg. 1997;12(2):276-284.

71. Stamou SC, Boyce SW, Cooke RH, Carlos BD, Sweet LC, Corso PJ. One-year outcome after combined coronary artery bypass grafting and transmyocardial laser revascularization for refractory angina pectoris. Am J Cardiol. 2002;89(12):1365-1368.

72. Wehberg KE, Julian JS, Todd JC, Ogburn N, Klopp E, Buchness M. Improved patient outcomes when transmyocardial revascularization is used as adjunctive revascularization. Heart Surg Forum. 2003;6(5):328-330.

73. Allen KB, Dowling RD, DelRossi AJ, et al. Transmyocardial laser revascularization combined with coronary artery bypass grafting: a multicenter, blinded, prospective, randomized, controlled trial. J Thorac Cardiovasc Surg. 2000;119(3):540-549.

74. Frazier OH, Boyce SW, Griffith BP, et al. Transmyocardial revascularization using a synchronized $\mathrm{CO} 2$ laser as adjunct to coronary artery bypass grafting: results of a prospective, randomized multi-center trial with 12-month follow-up. Circulation. 1999;100:I-1248.

75. Frazier $\mathrm{OH}$, Tuzun E, Eichstadt H, et al. Transmyocardial laser revascularization as an adjunct to coronary artery bypass grafting: a randomized, multicenter study with 4-year follow-up. Tex Heart Inst J. 2004;31(3):231-239. 
76. Eldaif SM, Lattouf OM, Kilgo P, Guyton RA, Puskas JD, Thourani VH Long-term outcomes after CABG with concomitant $\mathrm{CO} 2$ transmyocardial revascularization in comparison with $\mathrm{CABG}$ alone. Innovations (Phila). 2010;5(2):103-108.

77. Kim CB, Oesterle SN. Percutaneous transmyocardial revascularization. J Clin Laser Med Surg. 1997;15(6):293-298.

78. Lauer B, Junghans U, Stahl F, Kluge R, Oesterle SN, Schuler G. Catheter-based percutaneous myocardial laser revascularization in patients with end-stage coronary artery disease. J Am Coll Cardiol. 1999;34(6):1663-1670.

79. Oesterle SN, Sanborn TA, Ali N, et al. Percutaneous transmyocardial laser revascularisation for severe angina: the PACIFIC randomised trial. Potential Class Improvement From Intramyocardial Channels. Lancet. 2000;356(9243):1705-1710.

80. Stone GW, Teirstein PS, Rubenstein R, et al. A prospective, multicenter, randomized trial of percutaneous transmyocardial laser revascularization in patients with nonrecanalizable chronic total occlusions. J Am Coll Cardiol. 2002;39(10):1581-1587.

81. Leon MB, Kornowski R, Downey WE, et al. A blinded, randomized, placebo-controlled trial of percutaneous laser myocardial revascularization to improve angina symptoms in patients with severe coronary disease. J Am Coll Cardiol. 2005;46(10):1812-1819.

82. Stone GW, St Goar FG, Taussig A, Power JA, Kosinski E, Shawl F. First experience with hybrid percutaneous transmyocardial laser revascularization and angioplasty in patients with lesions at high risk for restenosis: Results of a phase I feasibility study. Am Heart J. 2001;142(4):679-683.

83. Assmus B, Schächinger V, Teupe C, et al. Transplantation of Progenitor Cells and Regeneration Enhancement in Acute Myocardial Infarction (TOPCARE-AMI). Circulation. 2002;106(24):3009-3017.

84. Assmus B, Fischer-Rasokat U, Honold J, et al; TOPCARE-CHD Registry. Transcoronary transplantation of functionally competent BMCs is associated with a decrease in natriuretic peptide serum levels and improved survival of patients with chronic postinfarction heart failure-results of the TOPCARE-CHD registry. Circ Res. 2007;100(8); 1234-1241.

85. Strauer BE, Brehm M, Zeus T, et al. Regeneration of human infarcted heart muscle by intracoronary autologous bone marrow cell transplantation in chronic coronary artery disease: the IACT Study. J Am Coll Cardiol. 2005;46(9):1651-1658.

86. Meyer GP, Wollert KC, Lotz J, et al. Intracoronary bone marrow cell transfer after myocardial infarction: 5-year follow-up from the randomized-controlled BOOST trial. Eur Heart J. 2009;30(24): 2978-2984.
87. Perin EC, Dohmann HF, Borojevic R, et al. Transendocardial, autologous bone marrow cell transplantation for severe, chronic ischemic heart failure. Circulation. 2003;107(18):2294-2302.

88. Zohlnhöfer D, Ott I, Mehilli J, et al; REVIVAL-2 Investigators. Stem cell mobilization by granulocyte colony-stimulating factor in patients with acute myocardial infarction: a randomized controlled trial. JAMA. 2006;295(9):1003-1010.

89. Patel AN, Geffner L, Vina RF, et al. Surgical treatment for congestive heart failure with autologous adult stem cell transplantation: a prospective randomized study. J Thorac Cardiovasc Surg. 2005;130(6):1631-1638.

90. Heldman AW, DiFede DL, Fishman JE, et al. Transendocardial mesenchymal stem cells and mononuclear bone marrow cells for ischemic cardiomyopathy: the TAC-HFT randomized trial. JAMA. 2014;311(1): 62-73.

91. Patel AN, Spadaccio C, Kuzman M, et al. Improved cell survival in infarcted myocardium using a novel combination transmyocardial laser and cell delivery system. Cell Transplant. 2007;16(9):899-905.

92. Babin-Ebell J, Sievers HH, Charitos EI, et al. Transmyocardial laser revascularization combined with intramyocardial endothelial progenitor cell transplantation in patients with intractable ischemic heart disease ineligible for conventional revascularization: preliminary results in a highly selected small patient cohort. Thorac Cardiovasc Surg. 2010;58(1):11-16.

93. Konstanty-Kalandyk J, Piątek J, Miszalski-Jamka T, et al. The combined use of transmyocardial laser revascularisation and intramyocardial injection of bone-marrow derived stem cells in patients with end-stage coronary artery disease: one year follow-up. Kardiol Pol. 2013;71(5): 485-492.

94. Reyes G, Allen KB, Alvarez P, et al. Mid term results after bone marrow laser revascularization for treating refractory angina. BMC Cardiovasc Disord. 2010;10:42.

95. Gowdak LH, Schettert IT, Rochitte CE, et al. Transmyocardial laser revascularization plus cell therapy for refractory angina. Int J Cardiol. 2008;127(2):295-297.

96. Gowdak LH, Schettert IT, Rochitte CE, et al. Cell therapy plus transmyocardial laser revascularization for refractory angina. Ann Thorac Surg. 2005;80(2):712-714.

97. Klein HM, Ghodsizad A, Borowski A, et al. Autologous bone marrowderived stem cell therapy in combination with TMLR. A novel therapeutic option for endstage coronary heart disease: report on 2 cases. Heart Surg Forum. 2004;7(5):E416-E419.

98. Shahzad U, Li G, Zhang Y, Yau TM. Transmyocardial revascularization induces mesenchymal stem cell engraftment in infarcted hearts. Ann Thorac Surg. 2012;94(2):556-562.
Medical Devices: Evidence and Research

\section{Publish your work in this journal}

Medical Devices: Evidence and Research is an international, peerreviewed, open access journal that focuses on the evidence, technology, research, and expert opinion supporting the use and application of medical devices in the diagnosis, treatment and management of clinical conditions and physiological processes. The identification of novel

\section{Dovepress}

devices and optimal use of existing devices which will lead to improved clinical outcomes and more effective patient management and safety is a key feature. The manuscript management system is completely online and includes a quick and fair peer-review system. Visit http://www. dovepress.com/testimonials.php to read real quotes from authors. 